Journal of Applied Biosciences 151: 15530 - 15539

ISSN 1997-5902

\title{
Evaluation of Cercospora oryzae Miyake under natural pressure conditions.
}

\author{
Gnancadja L. S. André1; Soura B. Hervé1; Koita Kadidia2; Gandonou Christophe; Baba-Moussa A. \\ K. Farid ${ }^{3}$ \\ 1 University of Abomey-Calavi. Faculty of Sciences and technologies. Department of Vegetable Biology. \\ 01BP526 Cotonou (Benin). Email: gnancadja@hotmail.com. sbanemane@yahoo.Fr. ganchrist@hotmail.com. \\ 2 University Ouaga I Pr Joseph KI-ZERBO. Faculty of Sciences and technologies. Department Biology and \\ Physiology Vegetal. (Burkina Faso). Email: benbakadi@yahoo.fr. \\ 3 University of Abomey-Calavi. Faculty of Sciences and technologies. Department of Vegetable Biology. \\ 01BP526 Cotonou (Benin). Email: fbmouss@yahoo.Fr. \\ Original submitted in on $20^{\text {th }}$ April 2020. Published online at www.m.elewa.org/journals/ on $31^{\text {st }}$ July 2020 \\ https://doi.org/10.35759/JABs.151.2
}

\begin{abstract}
Objective: This study is a contribution to the knowledge of Cercospora oryzae Miyake, in order to increase yields. It will consist in: i) evaluating the resistance of five varieties of rice, ii) evaluating the effect of Cercospora oryzae Miyake on the leaf and panicle stages and iii) evaluating the yield.

Methodology and results: The study will combine phenotypic and agromorphological tools. On the ninety first (91th) day after sowing, a high incidence of leaf Cercosporiosis was recorded on the varieties TS2 $(29.74 \%)$, FKR34 (27\%) and a very low incidence on the variety ORYLUX6 (5, 78\%). From tillering to panicle initiation, the rate of progression of the epidemic $r 2=0.879$ is significant in TS2. The ORYLUX6 variety is the most capable of slowing the progression of the epidemic. At the panicular level, from the pasty grain stage to the milky grain stage, the incidence has increased for most of the varieties. The ORYLUX6 recorded the highest yield with $4.38 \mathrm{t} /$ ha.

Conclusion and application potential of the results: Cercospora oryzae Miyake causes a drop in yieldby reducing the leaf area of thr leaves. Cercospora oryzae Miyake is an important disease of rice in SudBenin. These results constiyute a stage of an in-depth research work on the characterization (agronomic and genetic) of Cercospora oryzae Miyake in order to propose methods of control.
\end{abstract}

Key words: Cercospora oryzae, incidence, yield, rice, Benin.

\section{RESUME}

Objectifs : L'étude a été une contribution à la connaissance de Cercospora oryzae Miyake afin d'accroitre les rendements. Elle a consistée a : i) évaluer la résistance de cinq variétés de riz, ii) évaluer l'effet de Cercospora oryzae Miyake sur les stades foliaires et paniculaires et iii) évaluer le rendement.

Méthodologie et résultats: L'étude a combinée des outils phénotypiques et agromorphologiques. Au quatre-vingt onzième jour après semis on a enregistré une forte incidence de la cercosporiose foliaire sur les variétés TS2 (29,74\%), FKR34 (27\%) et une très faible incidence sur la variété ORYLUX6 (5,78\%). Du stade tallage à l'initiation paniculaire le taux de progression de l'épidémie $r 2=0,879$ a été important chez TS2. La variété ORYLUX6 a été la plus apte à freiner la progression de l'épidémie. Du stade grain pâteuX 
au stade grain laiteux l'incidence à augmentée pour la plus part des variétés. ORYLUX6 a enregistré le rendement le plus élève $(4,38 \mathrm{t} / \mathrm{ha})$.

Conclusion et application potentielle des résultats: Cercospora oryzae Miyake entraine une baisse de rendement en réduisant les surfaces foliaires des feuilles. La cercosporiose est une affection importante du riz au Sud-Bénin. Ces résultats constituent une étape d'un travail de recherche approfondi sur la caractérisation (agronomique et génétique) de Cercospora oryzae Miyake afin de proposer des méthodes de luttes.

Mot clés : Cercospora oryzae, incidence, rendement, riz, Bénin.

\section{INTRODUCTION}

The economy of most Sahelian countries is essentially based on agro-pastoral resources. Cereal production is one of the main agricultural activities (Ouédraogo, 2008). This production has improved considerably in recent decades thanks to innovations brought by new technologies developed by agricultural research institutes (FAO, 2017). These have contributed to a significant increase in the level of production in most countries. The production of traditional cereals, which covers the majority of the cultivated areas, is dependent on rainfall. For more than twenty years, the installation of the persistence of drought and diseases in the Sahelian ecology has only worsened. In Benin, rice currently represents the third cereal in terms of production, after maize and sorghum (CCR-B, 2012). Rice production decreases from year to year in Benin with the appearance of new biotic constraints (diseases) due to overuse of land and monoculture. New thinking had led to the redefinition of need (Nonfon, 2005). An organization of producers, a public and private partnership in development, a manifest of political will and an implication of the technical and financial partners in the actions of promotion of the sector are noted (SNDR, 2011). Despite all this, rice production remains very low to cover the internal needs of the population. Rice

\section{MATERIAL AND METHODS}

Study site: The study was conducted in Benin, a country located in West Africa. Benin is one of the smallest countries in Africa. The study concerned the Docomey irrigated perimeter site in the Ouémé Valley in the local government area of Zinvié, about $20 \mathrm{~km}$ from Abomey-Calavi on the National Road No. 1. This perimeter, which covers an area of 70 ha, has been production is facing various biotic and abiotic constraints. Diseases are the most important constraints in southern Benin. Rice Sigatoka is more present in rice fields, constituting a brake on production. This disease prevents the achievement of the yield potential of so-called resistant varieties, all the more since the difficulties lie in the fact that the producers do not know how to distinguish this pathology and confuses it with the complexes of leaf diseases, therefore suitable control methods are not envisaged subsequently causing epidemics and considerable reductions in yield. The experience of viral rice diseases which appeared with the green revolution in Asia, shows us that control methods can only be effective and efficient when they are based on a thorough knowledge of the disease (characteristics of the inoculum fungus, modality of transmission, disease ecology, sources and nature of resistance) (Groth, 2007). For these reasons, knowledge of the bio-ecology of the causative agent of fungal diseases in this case the Sigatoka of rice becomes a priority if we want to secure agricultural production. This work is part of a better understanding of the bio-ecology of the causative agent of Sigatoka (Cercospora oryzae) and the evaluation of the resistance of varieties in order to increase yields.

developed since 2009. Two rice growing campaigns are carried out each year, one in the wet season and the other in the dry season.

Plant material: A collection of 5 varieties of rice, made up of interspecific hybrids from crosses between the two species Oryza sativa and O. glaberrima were used for this study. The interspecific hybrid of the flooded 
type (IR841) was selected as a control for its good behaviour in moderate submergence conditions, resistant to pyriculariosis and sensitive to drought. The other varieties are of flooded ecology, which can be cultivated also in rainwater ecology. Their cycle varies between 90 to 129 days.

Experimentation methods: The trial was conducted using a complete randomized Fisher block device. Each block has five (05) elementary plots (PE). Four (04) lines of $4.20 \mathrm{~m}$ each form the elementary plot. The spacing was $30 \mathrm{~cm}$ between the lines and $15 \mathrm{~cm}$ between the pockets, $30 \mathrm{~cm}$ between the elementary plots and $1.5 \mathrm{~m}$ between the blocks (repetitions). The PE has 112 pockets. The blocks were repeated three times (photo 1) real medium. The observations related to 30 fixed pockets at the level of the elementary plot
(PE). The development of the disease was followed by transplanting until maturity. The preparation of the soil consisted of ploughing, harrowing, levelling and staking. Follow-up of a transplanting and a complement of missing pockets made 14 days after transplanting. The rice was sown in the nursery on February 18, 2019 (photo 32) and transplanted one strand per pocket 15 days after sowing, i.e. March 05, 2019. Two mineral fertilizers were brought to the site: NPK, formula 14-23 14 , was applied as background manure at sowing, at the dose $300 \mathrm{~kg} / \mathrm{ha}$ and urea (46\% nitrogen) was applied as cover manure, at the dose of $150 \mathrm{~kg} / \mathrm{ha}$ in two fractions: $75 \mathrm{~kg} / \mathrm{ha} 35$ days after transplanting and $75 \mathrm{~kg} / \mathrm{ha}$ at panicle initiation. Manual weeding was carried out twice. The irrigation water was brought in according to the crop's water needs.

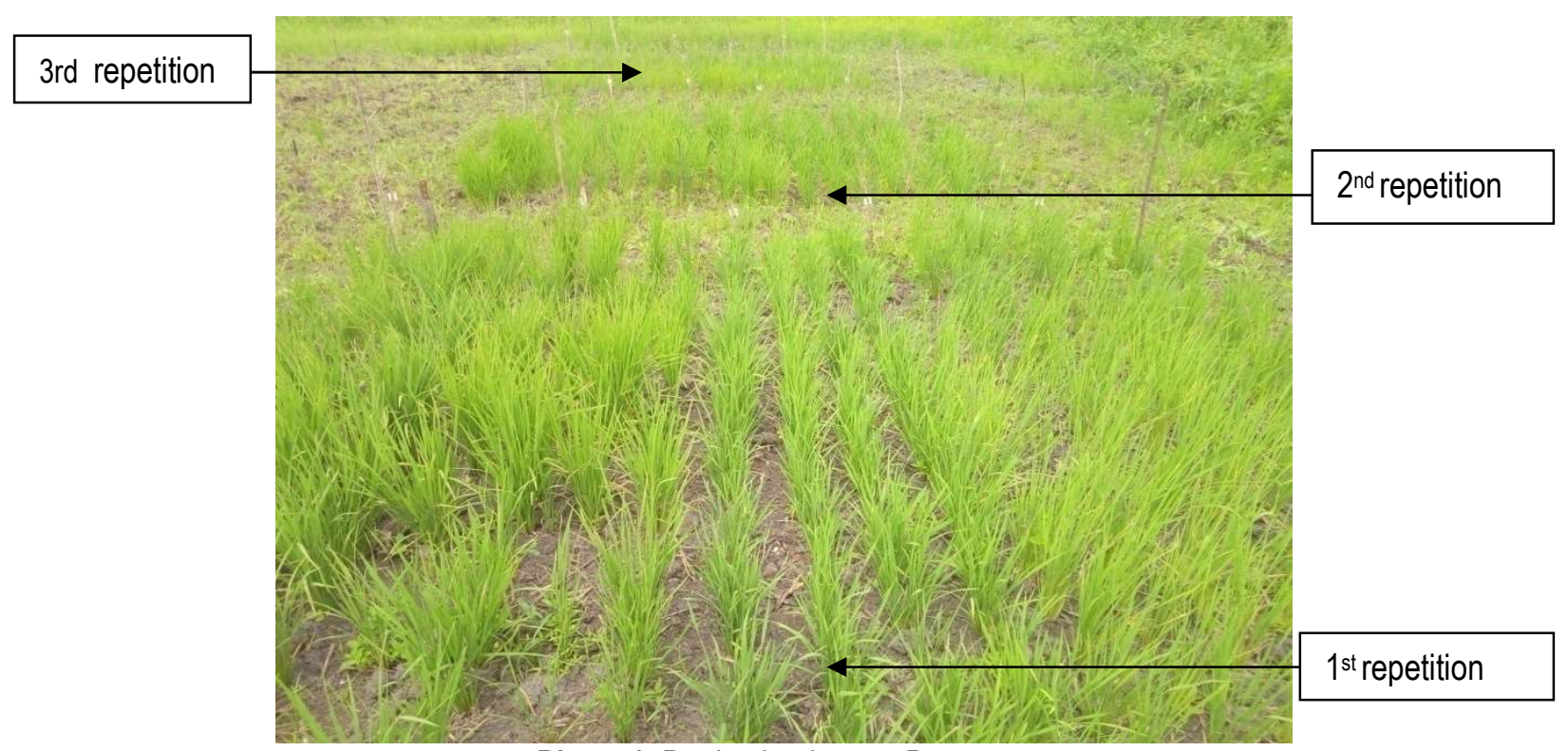

Photo 1: Device in place at Docomey

Source: Soura, 2019

Parameters evaluated: The leaf incidence is evaluated, every seven days, from the 21 st to the 91 st day after sowing (transplanting) (JAS). The scores are assigned by pocket and expressed as a percentage of diseased leaf area (\% SFM);

- The panicle incidence expressed as a percentage of diseased panicles is evaluated every seven days on two fixed lines at the level of each elementary plot. Observations range from the 10th to the 31 st day after heading (JAE).
- The rate of progression of the epidemic ( $r$ ) expressed in units per day is evaluated by the method described by Rapilly (1991):

$r($ unit $/$ day $)=[\log (1 / 1-x 2)-\log (1 / 1-x 1)] /(t 2-t 1)$

Where: $x 1$ and $x 2$ denote the quantities of disease expressed as a percentage and (t2 - t1) is the time interval of seven days between two observations. This time interval is a function of the possibilities of dissemination of the pathogen and the length of the receptive period of the host; 
- The area of disease progression or Area Under the Disease Progress Curve (AUDPC) is calculated according to the formula (Shaner and Finney, 1977):

AUDPC $=\Sigma[(\mathrm{Di}+\mathrm{Di}+1) / 2](\mathrm{ti}+1-\mathrm{ti})$

Where: $\mathrm{Di}$ and $\mathrm{Di}+1$ are the incidences of the disease expressed, percentage of diseased leaf area (SFM) and which are observed respectively at times $\mathrm{ti}+1$ and ti; $\mathrm{ti}$

\section{RESULTS}

Incidence of leaf spot Cercosporiosis: The data for the incidence of leaf spot Sigatoka in Docomey have been given in Table 1 . These data indicates an increase in the incidence of the disease from the 49th JAS, with a maximum at the end of the plant cycle. The, statistical analysis shows that there is a very high significant statistical difference between the varieties:

- At the tillering stage (between 35 and 42 JAS), the intensity of the disease was very low. The leaf incidence of the disease (\% SFM) varied from $0.00 \%$ to $5.33 \%$ for the varieties studied, control IR841 showing no leaf symptoms until the 42nd JAS. Forty-two days after sowing, the four varieties of rice studied showed symptoms of leaf attack. These are FKR62N (V1), TS2 (V2), ORYLUX6 (V3) and FKR34 (V4). A single variety FKR34 had more than $3 \%$ SFM.

- From the end tillering stage to the panicle initiation (between 42 and 56 JAS), we observed a more marked progression of the disease in the varieties studied. Thus, the varieties TS2 (6.22\%), FKR34 (10\%) and FKR62N (4.22\%) presented more than 3\% SFM and the variety ORYLUX6 $(1.78 \%)$ presented less than $3 \%$ SFM as well witness IR841 (4.98\%).

- From the early swelling stage to the beginning of the heading (between 56 and $70 \mathrm{JAS}$ ), the variety
+1 - ti) represents the time interval in days between two observations;

Statistical analysis: The raw data was typed using Excel, also the construction of the curves and histograms. The analysis of variance was carried out using the XLSTAT software and the comparison of the means was made according to the DUNCAN test at the threshold of $5 \%$.

FKR34 (V4) remained the most attacked with 15.17\% SFM followed by the variety FKR62N (V1) with 14.12\% SFM and $13,11 \%$ for TS2 (V2). The disease has progressed for all the varieties studied as well as for the resistant control IR841 (8.11\%);

- From the early heading stage to the pasty grain stage (from 70 to $91 \mathrm{JAS}$ ), it was found that, unlike the previous stage (56 - $70 \mathrm{JAS}$ ), the levels of leaf infection varied in various ways. There were two cases: the varieties, which did not experience any major variation in the incidence of the disease. It is mainly the variety ORYLUX6 (V3). Varieties with an increased incidence of the disease. More specifically, these are V2 (TS2), V4 (FKR34) and V1 (FKR62N).

- Seventy-seven days after sowing, the ORYLUX6 (V3) variety had a leaf incidence of $5.34 \%$, thus demonstrating a good level of resistance. FKR34 (V4) remained the most attacked variety with $21.06 \%$ of diseased leaf area.

- After 91 JAS, the TS2 variety recorded the strongest attack with $29.74 \%$ of diseased leaf area followed by FKR34 27\% of diseased leaf area. A single ORYLUX6 (V3) variety had less than $6 \%$ of diseased leaf area and was found to be resistant to $C$. oryzae attack.

Table 1: Evolution of the incidence of leaf spot Sigatoka in Docomey during the 2019 season.

\begin{tabular}{|c|c|c|c|c|c|c|c|c|c|c|}
\hline \multirow{2}{*}{$\begin{array}{l}\text { Entry } \\
\text { Code }\end{array}$} & \multirow{2}{*}{$\begin{array}{l}\text { Variety of } \\
\text { Rice }\end{array}$} & \multicolumn{9}{|c|}{ Leaf area in (\%) } \\
\hline & & 35JAS & 42JAS & 49JAS & 56JAS & 63JAS & 70JAS & 77JAS & 84JAS & 91JAS \\
\hline V1 & FKR62N & 0,20 & 2,14 & 3,52 & 4,25 & 8,10 & 14,12 & 14,12 & 18,11 & 18,11 \\
\hline V2 & TS2 & 0,00 & 0,47 & 1,63 & 6,22 & 10,12 & 13,11 & 18,98 & 27,55 & 29,74 \\
\hline VT & IR841 & 0,00 & 0,00 & 2,14 & 4,98 & 7,58 & 8,11 & 10,11 & 13,08 & 15,08 \\
\hline V3 & ORYLUX6 & 0,00 & 0,13 & 1,22 & 1,78 & 4,77 & 5,15 & 5,34 & 5,49 & 5,78 \\
\hline V4 & FKR34 & 0,65 & 5,33 & 9,17 & 10,00 & 12,68 & 15,17 & 21,06 & 26,12 & 27,00 \\
\hline \multicolumn{2}{|c|}{$\begin{array}{l}\text { Standard } \\
\text { deviation }\end{array}$} & 0,02 & 0,11 & 0,35 & 2,14 & 6,18 & 9,31 & 15,25 & 18,86 & 19,17 \\
\hline \multicolumn{2}{|c|}{ Probability } & \multicolumn{9}{|c|}{$<0,0001$ THS } \\
\hline \multicolumn{2}{|c|}{ Average } & 0,16 & 1,62 & 3,52 & 5,10 & 7,85 & 10,30 & 12,73 & 16,17 & 17,09 \\
\hline
\end{tabular}

JAS: Day After Sowing, THS: Very Highly Significant

NB: The numbers affected by the same letter are statistically equivalent according to the DUNCAN test at the threshold of $5 \%$. 
Classification of rice varieties according to their level of tolerance to Cercosporiosis leaf spot: Data on the incidence of Cercosporiosis leaf 84 JAS grouped rice varieties into disease susceptibility groups according to the IRRI rating scale (2002). The results of these groupings are shown in Table 2. This classification of varieties according to their level of susceptibility to the disease makes it possible to distinguish three (03) groups:
Group I of resistant varieties with an incidence between $1 \%$ and $10 \%$ of SFM. This group consists of an entry the ORYLUX6.

Group II of moderately resistant varieties with an incidence between $11 \%$ and $25 \%$ SFM. This group also consists of an entry, the FKR62N. Witness IR841 is found there.

Group III of susceptible varieties with an incidence between $25 \%$ and $50 \%$ SFM. There are varieties like TS2, FKR34. Photo 2 illustrates the field condition of a susceptible variety and a resistant variety.

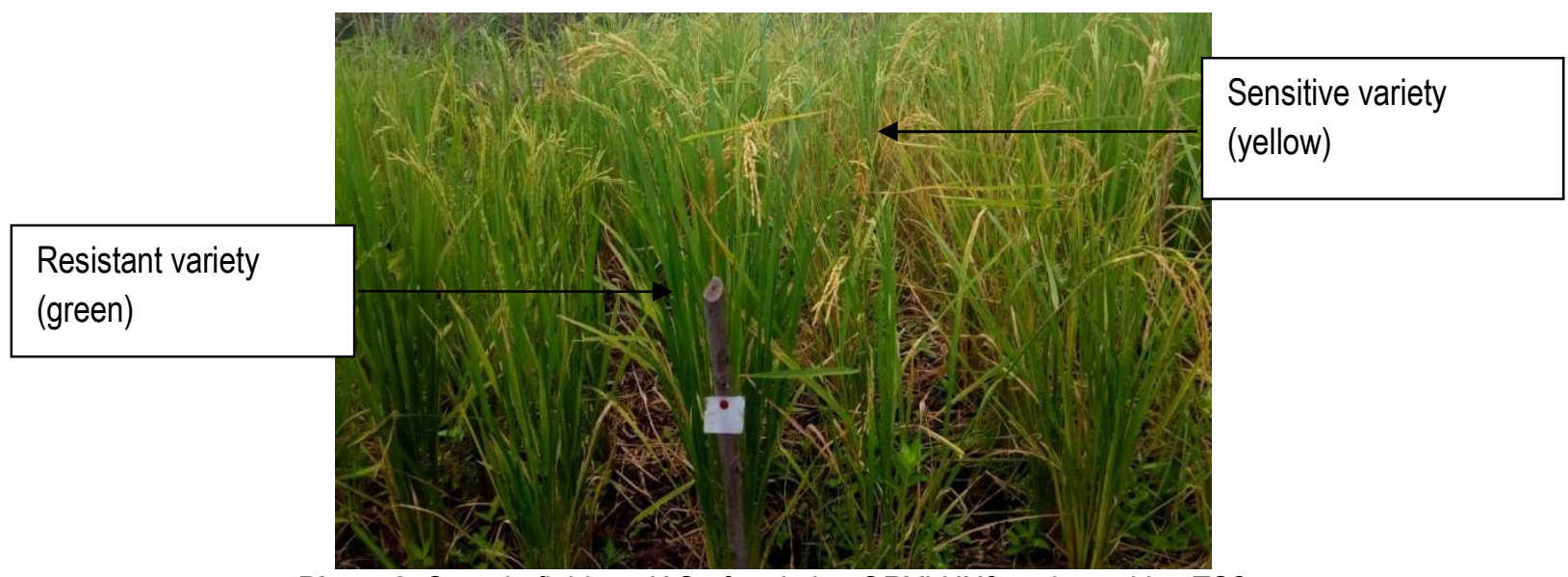

Photo 2: State in field 77 JAS of varieties ORYLUX6 and sensitive TS2

Source: Soura, 2019

Table 2: Classification of rice varieties in groups susceptible to leaf attack caused by Cercospora oryzae at Docomey during the 2019 rain season

\begin{tabular}{|l|l|l|l|}
\hline Group & \multicolumn{2}{|l|}{ Rice Genotype } & Resistance level \\
\hline Group I & V1 & ORYLUX6 & $\begin{array}{l}\text { Resistante varieties (lower incidence } \\
\text { to 10\% SFM) }\end{array}$ \\
\hline Group II & V3 & FKR62N & $\begin{array}{l}\text { Moderately resistant varieties (from 11 to 25\% } \\
\text { SFM) }\end{array}$ \\
\hline & VT & IR841 & $\begin{array}{l}\text { Sensitive varieties (upper incidence (from 25 to } \\
50 \% \text { SFM) }\end{array}$ \\
\hline Group III & V4 & TS2 & \\
& V5 & FKR34 &
\end{tabular}

Evolution of the leaf epidemic cercosporiosis spot in rice: The behaviour of rice varieties with regard to leaf cercosporiosis was studied using two variables: the rate of epidemic progression ( $r$ ) and the area of disease development (AUDPC).

Foliar epidemic progression: The rates of progression of the Docomey leaf epidemic cercosporiosis $(r)$ during the 2019 rain season were calculated according to the formula of Rapilly (1991) and grouped in Table 3. At tillering stage, the rate of progression of the epidemic ( $r 1)$ is low for the variety
ORYLUX6 (0.007) and TS2 (0.024). It is high for the varieties FKR34 (V4) or $(r=2,788)$ and FKR62N or $(r=$ $1,428)$ and zero $(r=0.000)$ for the control variety IR841. From tillering to panicle initiation (56 JAS), the rate of epidemic progression ( $r 2$ and $r 3$ ) has varied considerably, from 0.009 (VT) to 4.985 (V2). The TS2 variety, which was the most heavily, attacked with $29.74 \%$ SFM, experienced an epidemic progression rate $(r 2)$ of 0.879 . This indicates a rapid progression of the disease. At panic initiation, TS2 (V2) had the highest rate of epidemic progression ( $r 3$ ) with a value of 
4.986. From the beginning of the swelling stage to the head (between 56 and 91 JAS), the progression rates $r 4, r 5, r 6, r 7$ and $r 8$ were variable.TS2 (V2) confirms its sensitivity to the disease with a progression rate $(r 8)$ of 1.164. The study of the rate of progression of the epidemic during the study period revealed a notable difference in the behaviour of the varieties. When the average rate of progression of the disease over the entire observation period (average) was considered, for a V3 entry (ORYLUX6) this progression rate was less than 1 . This made it possible to classify among the material having a good level of general resistance. For inputs V1 (FKR62N), V2 (TS2) and V3 (FKR34), this rate varied from 2.282 to 2.458 . Most varieties have known a constant progression of the epidemic until the end of their vegetative cycle.

Table 3: Rate of progression of the leaf epidemic cercosporiosis according to rice varieties during the 2019 rain season on the Docomey site.

\begin{tabular}{|c|c|c|c|c|c|c|c|c|c|c|}
\hline \multirow{2}{*}{$\begin{array}{l}\text { Entry } \\
\text { code }\end{array}$} & \multirow[t]{2}{*}{ Rice varieties } & \multicolumn{9}{|c|}{ Epidemic rate of progression $(r)$} \\
\hline & & rmoyen $^{*}$ ) & $\left.r 11^{* *}\right)$ & r2 & r3 & r4 & r5 & r6 & r7 & r8 \\
\hline V1 & FKR62N & 2,282 & 1,428 & 0,081 & 0,974 & 2,876 & 2,758 & 0,000 & 1,872 & 0,821 \\
\hline V2 & TS2 & 2,458 & 0,024 & 0,879 & 4,986 & 3,034 & 3,008 & 3,969 & 4,185 & 1,164 \\
\hline VT & IR841 & 1,207 & 0,000 & 0,009 & 1,874 & 0,015 & 0,872 & 0,095 & 0,279 & 0,508 \\
\hline V3 & ORYLUX6 & 0,349 & 0,007 & 0,158 & 0,064 & 1,078 & 0,719 & 0,912 & 0,039 & 0,014 \\
\hline V4 & FKR34 & 2,351 & 2,788 & 2,974 & 0,927 & 1,023 & 2,362 & 4,731 & 3,812 & 0,994 \\
\hline
\end{tabular}

$\left({ }^{*}\right)$-the epidemic rate of progression over the entire observation period from 35 to $91 \mathrm{JAS}$;

$\left(^{* *}\right)$ - weekly progression rate: r1 (from 35 to 42 JAS), r2 (from 42 to 49 JAS), r3 (from 49 to 56 JAS), r4 (from 56 to 63 JAS), r5 (from 63 at $70 \mathrm{JAS}$ ), r6 (from 70 to $77 \mathrm{JAS}$ ), r7 (from 77 to $84 \mathrm{JAS}$ ) and r8 (from 84 to $91 \mathrm{JAS}$ ).

Disease Development Area (AUDPC): The incidence of the disease expressed throughout the area variable under the disease progression curve (AUDPC), for each variety of rice, is illustrated in Figure 1. This figure represents the cumulative AUDPC at the different dates of observation at Docomey during the 2019 rain season. The graph shows that the AUDPC index varied from a minimum value of 290 for the variety V3 (ORYLUX6) to a maximum value greater than 1100 for V2 (TS2). The highest values of the AUDPC index are found for the varieties, which have had the highest leaf incidence. These are the varieties TS2 (V2), FKR34 (V4), FKR62N (V1), with values of 1100, 1015, 600 and
520 respectively for the control IR841 (VT). AUDPC is a good indicator of the level of general or polygenic resistance of the varieties studied. The results obtained indicate a continuous variation in the values of this index, reflecting differentiated levels of general resistance within the material studied. The varieties most capable of slowing the progression of the disease are those capable of limiting the overall incidence of the disease expressed by a weak AUDPC ORYLUX6 (V3). The differentiation of genotypes by this index confirms the classification based on the severity of the leaf incidence. 


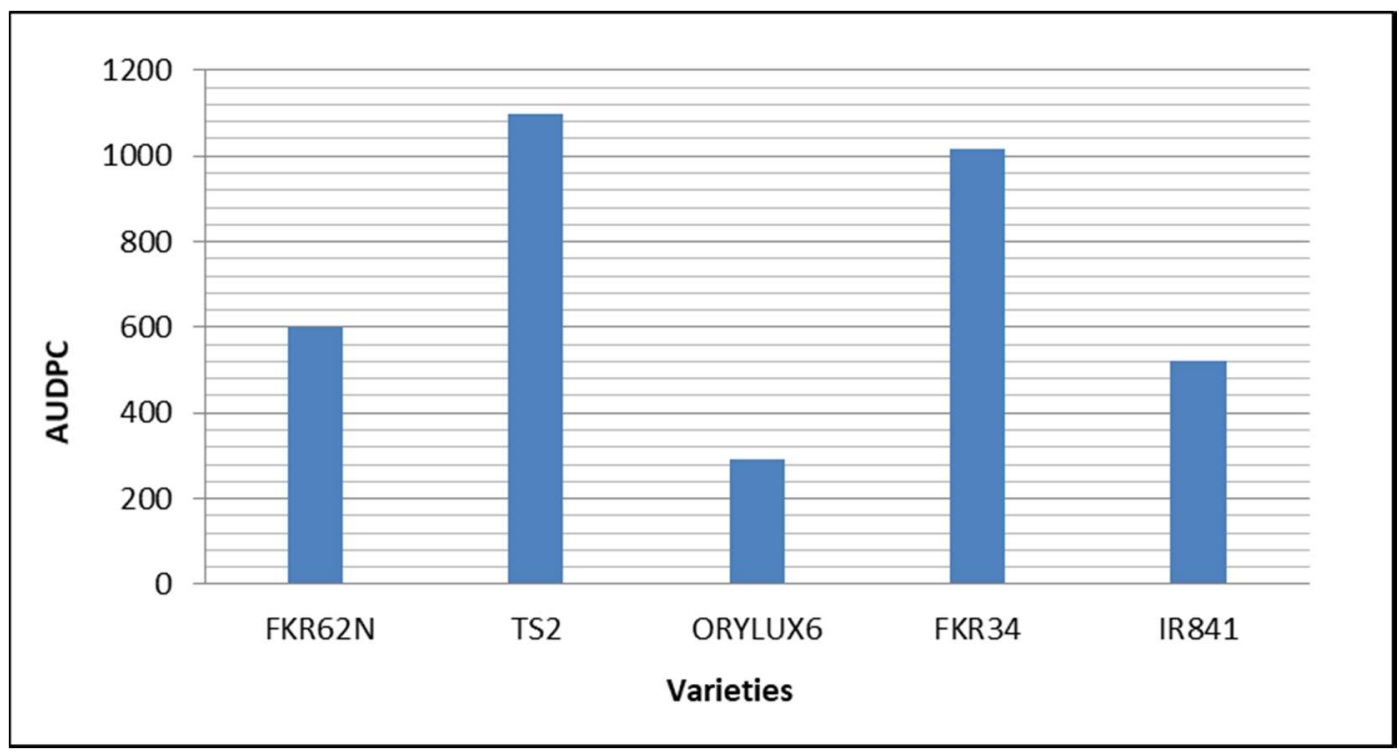

Figure 1: Histogram of classification of rice varieties according to the AUDPC index accumulated at Docomey during the 2019 rain season.

Incidence of Panicular Cercosporiosis: The results of observations of the incidence of Cercosporiosis and the epidemic rates of progression are collated in Table 4. They indicate a continuous progression of the Cercosporiosis epidemic from the beginning of the heading to the pasty grain stage of rice: From the start of the ear to the milky grain stage (between 10 and 17 $\mathrm{JAE}$ ), all the varieties evaluated showed symptoms of the disease. Ten days after heading two entries, including TS2 and FKR34, indicated more than $10 \%$ of panicles attacked. The ORYLUX6 varieties and the IR841 control demonstrated a good level of resistance to panic attack, with an incidence of $6.75 \%$ for VT (IR841) to $4.77 \%$ for V3 (ORYLUX6). From the milky grain stage to the pasty grain stage (between 24 and 31 $\mathrm{JAE}$ ), the incidence of the disease increased considerably for most of the varieties studied. It reached a maximum value of $30.08 \%$ of sick panicles for TS2 (V2). The varieties FKR34 (V4), TS2 (V2) confirmed their sensitivity to leaf attack by $C$. oryzae and were strongly attacked, with a panicle incidence greater than $20 \%$ of diseased panicles. The rates of progression of the panic epidemic ranged from 0.08 to 4.84 over the reporting period. The progression of panicular disease was significantly delayed in ORYLUX6 (V3) at the start of the headset ( $11=0.08)$; however, it was very strong for other varieties such as FKR34 (V4) and TS2 (V2), with growth rates of 1.97 and 3.17 respectively. Two varieties have shown an ability to slow the progression of the disease at the beginning of the heading ( $\mathrm{r} 1$ ); these: are V1 (FKR62N), V3 (ORYLUX6). At the end of the cycle (31 JAE), two varieties (V1, V3) were found to be the most capable of slowing the epidemic ( $r 3$ ) with the lowest rate of progress, $r 3=0.45$ and 0.43 respectively. Varieties TS2 (V2) and FKR34 (V4) displayed a high rate of progression of panicular disease ( $\mathrm{r} 2$ ) ranging from 3.90 to 4.84 respectively. 
Table 4: Evaluation of the rate of sick panicle and the progression of panicular leaf spot.

\begin{tabular}{|l|l|l|l|l|l|l|l|l|}
\hline \multirow{2}{*}{$\begin{array}{l}\text { Code } \\
\text { d'entré }\end{array}$} & Variétés de riz & \multicolumn{3}{|l|}{ Taux des panicules malades(\%) } & \multicolumn{3}{l|}{$\begin{array}{l}\text { Taux de progression de la } \\
\text { maladie }\end{array}$} \\
\cline { 3 - 9 } & & $\begin{array}{l}10 \\
\text { JAE }\end{array}$ & $\begin{array}{l}17 \\
\text { JAE }\end{array}$ & $\begin{array}{l}\mathbf{2 4} \\
\text { JAE }\end{array}$ & $\begin{array}{l}\text { 31 } \\
\text { JAE }\end{array}$ & r1 & r2 & r3 \\
\hline V1 & FKR62N & 8,75 & 14,18 & 18,88 & 18,25 & 0,976 & 1,021 & 0,459 \\
\hline V2 & TS2 & 10,25 & 15,11 & 28,38 & 30,08 & 3,178 & 3,90 & 1,664 \\
\hline VT & IR841 & 6,75 & 8,17 & 10,87 & 14,65 & 0,55 & 0,44 & 0,76 \\
\hline V3 & ORYLUX6 & 4,77 & 7,48 & 7,19 & 8,09 & 0,08 & 0,61 & 0,43 \\
\hline V4 & FKR34 & 12,68 & 21,24 & 26,72 & 27,92 & 1,97 & 4,84 & 2,97 \\
\hline Coefficient de variation & 0,97 & 0,59 & 0,38 & 0,34 & & & \\
\hline $\begin{array}{l}\text { Niveau de signification } \\
\text { (p=0,05) }\end{array}$ & HS & HS & HS & HS & & & \\
\hline
\end{tabular}

JAE : Day after heading, $R=$ progression rate

Yield: The average paddy grain yield is grouped in Table 5. It is noted that: The ORYLUX6 variety obtains the best yield with 4.38 tha followed by the control IR841 that obtains after analysis 3.80 tha. There is a very highly significant statistical difference between the yields of the different varieties. The lowest yield of the site is obtained by the variety FKR34 with 2.86 t/ha.
The average yield of all the plots is 3.80 tha. The majority of the varieties showed a yield higher than $3 \mathrm{t} /$ ha. These yields are always lower than the various potential yields. Only the variety FKR34 recorded a yield of less than 3 tha. While the other three varieties recorded a yield of more than $3 \mathrm{t} / \mathrm{ha}$.

Table 5: Paddy grain yields

\begin{tabular}{|l|l|}
\hline Varieties & Yield (t/ha) \\
\hline ORYLUX6 & $4,38 \mathrm{a}$ \\
\hline IR841 & $3,80 \mathrm{a}-\mathrm{b}$ \\
\hline TS2 & $3,52 \mathrm{a}-\mathrm{b}$ \\
\hline FKR62N & $3,04 \mathrm{a}-\mathrm{b}$ \\
\hline FKR34 & $2,86 \mathrm{c}$ \\
\hline Ecart-type & 0,45 \\
\hline Probalility & $<0,0001$ \\
\hline Average & 3,80 \\
\hline
\end{tabular}

Numbers with the same letter in the column are statistically equivalent according to the DUNCAN test at the $5 \%$ threshold.

\section{DISCUSSION}

The results obtained during this study highlight the importance of cercoporiosis in Docomey. Indeed, it noted that the incidence of the disease differs according to the varieties. The variations observed in the behaviour of rice varieties could be due to abiotic and biotic factors. Payasi and Singh (2001) observed differences in behaviour towards the disease linked not only to rice varieties, but also to the level of fertilization. According to Fomba (1991), nitrogen plays a minimal role in the severity of the disease, which tends to confirm the importance of other macro elements in the etiology of Cercosporiosis. In all cases, it appears that the disease is strongly favoured by a nutritional imbalance, which can have several origins. The variation observed in the behaviour of the material studied according to the site concerned could reveal differences linked to the genetic composition of Cercospora oryzae populations. Statistical analysis reveals a significant difference related to the variety factor, regardless of the date of observation considered. This hypothesis is shared by several authors (Saifulla, 1994; Datnoff and Lentini, 1994; Rai et al, 2004), who also admit that there is a difference in sensitivity to attacks by Bipolaris oryzae linked to varieties of rice. This situation is undoubtedly due to a very diverse genetic base within the plant material studied. This could reflect the lack of correlation between the leaf and panicle attacks of Cercospora oryzae. The start date 
and progression of the leaf epidemic vary according to the varieties studied and no variety is free from the disease. Thus, ORYLUX6 and IR841 show a good ability to slow the progression of infection at the start of the cycle (from the 49th JAS) with a disease progression rate for these varieties varying from 0.05 (r1) to 0,61 (r2). This has reduced the overall incidence of the disease, which ranges from $3.75 \%$ to $8.09 \%$ FMS. In the case of the most sensitive inputs V2 (TS2) and V4 (FKR34), this rate varied from $10.25 \%$ to $30.08 \%$; these varieties are thus 3 to 4 times more sensitive to Cercosporiosis than control IR841. This diversity of behaviour translates two scenarios. In the first case, it is a vertical resistance that delays the onset of the disease. In the second case, the progression of the disease is only delayed. This behaviour of rice varieties makes it possible to envisage the presence of several virulence genes within the population of the pathogen. This results in a horizontal or polygenic resistance type reaction, which results in a slow evolution of the epidemic. This is the case for group I varieties resistant to Sigatoka. The evolution of the epidemic's progression rate shows two peaks. These periods correspond to the stages of full tillering, ascent and the beginning of the heading. This finding may reflect the increased vulnerability of rice to leaf attack by Cercospora oryzae during these stages. Linear regressions of leaf attacks during these stages on temperature and humidity show a significant correlation. Climatic factors thus seem to play a predominant role in the establishment and progression of the epidemic (Agarwall et al., 1994; Moletti et al., 1994; Mondal et al., 1998). Two varieties of rice studied (TS2, FKR34) are more or less sensitive to the panic attack of Sigatoka, The rice varieties seem more vulnerable to the attack of Cercospora oryzae in the milky stage (three weeks after

\section{CONCLUSION AND APPLICATION OF RESULTS}

This study reveals a difference in behaviour of the varieties studied with regard to Sigatoka in conditions of natural disease pressure in the field. The reaction of the plant material studied reflects a diversity in the composition of the different populations of Cercospora oryzae. The yield losses observed suggests that Sigatoka is a potential threat to rice. Sigatoka caused losses ranging from $20 \%$ to $55 \%$ of production depending on the susceptibility of the different varieties to the disease, which constitutes a real shortfall for the producer. Cercosporiosis with high foliar and panicular heading) we consider the evolution of the panic epidemic.We found better behaviour of the ORYLUX6 variety, with lower leaf and panicular incidences of Sigatoka and a greater ability to slow the progression of the disease. The ecological factor does not seem to exert a repressive effect on these varieties, probably in connection with the greater plasticity of this plant material. This would allow it not only to withstand the flood, but also to take better advantage of production factors such as fertilizers. Overall yields were low compared to the production potential of each variety. In fact, only the ORYLUX6 variety exceeded a yield of $4 \mathrm{t} /$ ha with a potential of $6.5 \mathrm{t} / \mathrm{ha}$. With control IR841, a yield of $3.80 \mathrm{t} /$ ha was obtained with a potential of $8 \mathrm{t} /$ ha and with TS2 a yield of $3.52 \mathrm{t} / \mathrm{ha}$ was obtained with a potential of $8 \mathrm{t} / \mathrm{ha}$. In view of these low yields, we can say that Sigatoka has played a major role in this drop in productivity with a high incidence observed during the campaign. These results are even more interesting in that they highlight the realities experienced by producers. Sigatoka as other fungal diseases of rice rarely destroy $100 \%$ of production, it contributes to a decrease in productivity, preventing the varieties to reach the maximum of their productions. For a variety, that has a production potential of $8 \mathrm{t} / \mathrm{ha}$, we find ourselves at harvest with $3 \mathrm{t} /$ ha which constitutes a real shortfall for a producer. These results once again demonstrate the need to better study this disease in order to be able to control it. Climatic conditions at certain stages of development (Temperature, Relative Humidity) are also a determining factor in the development of fungal diseases (Diarra, 2000). Varieties attacked in the field can keep the fungus in the seed coats of their seeds for more than three years and thus constitute vectors (Agarwal et al., 1994).

incidence leads to complete discoloration of the leaves, therefore a reduction in leaf areas, thereby at the same time reducing the photosynthetic activity and therefore poor grain filling when the panicular leaf is strongly attacked. Sigatoka occurs at all stages of the rice plant's development. It is desirable to continue investigations on this disease in a larger number of localities and in at least two campaigns. This will make it possible to better understand the diversity within populations and the real level of parasite pressure of $C$. oryzae, but also to propose a control method. 


\section{ACKNOWLEDGEMENT}

We thank AfricaRice and INERAB Bobo Dioulasso for providing us with the seeds.

\section{REFERENCES}

Agarwal, P. C. Nieves Mortensen, C. Mathur, S. B. 1994. Rice diseases transmitted by seeds and phytosanitary tests. CTA / WARDA, ISBN 92 9081/1145, 93p.

CCR-B. 2012. Institutional support to producer organizations for the development of agricultural sectors. Envelope B of the 10th European Development Fund for Benin. CTB Benin/Bohicon. 18p.

Datnoff, L. E. Lentini, R. S. 1994. Brown Spot in Florida Rice. Plant Pathology Department. Institute of Food and Agricultural Sciences. University of Florida. Publication may 1994, $128 \mathrm{p}$.

Diarra, S. B. Staaz J. M. Bingen, J. R. Dembele, N. N. 2000. The reform of rice milling and marketing in the office of Niger: catalyst for an agricultural success story in Mali. Forthcoming in democracy and development. Bingen Robinson and Staatz, East Lansing, Ml, Michigan State University Press, USA.

FAO. 2017. Rice Market Monitoring (SMR), Report, Vol XX, Ed 1, 10p.

Fomba, S. N. 1991. Crop losses by Brown spot disease in mangrove swamps of Northwest Sierra Leone. Tropical Pest Management 36 (4) 367393.

Groth, D. E. 2007. Controlling Narrow Brown Leaf Spot. Louisiana Agriculture 50 (3): 22p.

Moletti, M. Giudici, M. L. Villa, B. 1994. Rice Akiochibrown spot disease in Italy: Agronomic and chemical control. Mediterranean Options Notebooks, Vol. 15, No. 3. 79-85.

Mondal, A. M. Mia, M. A. T. Ali, A. 1998. Relationship between brown leaf spot and grain spot and planting value of spotted rice. Seed-ResearchNew Delhi. India, 26 (1) 73-77.

Nonfon, M. 2005. L'appui au décorticage du riz paddy dans le département des Collines l'expérience de VECO Bénin et ses partenaires. 28p.

Ouedraogo, I. 2001. Study of some isolates of Bipolaris oryzae pathogen of rice helminthosporiasis in Burkina Faso. DEA thesis. University of Ouagadougou, UFR-SVT, BP 7021 Burkina Faso, 61p.

Ouédraogo, I. 2008. Incidence of rice helminthosporiasis in Burkina Faso and characterization of the pathogen populations
[Bipolaris oryzae (Breda de Haan) Shoemaker]. Doctoral thesis, University of Ouagadougou, Applied Biological Science, phytopathology option. 150p.

Payasi, S. K. Singh, A. K. 2001. Stability for disease resistance, yield and yield attributes in rice. Crop Research Hisr. 21 (2): 188-191.

Rai, B. Jha, M. M. Jha, A. C. 2004. Screening of resistant sources of rice against brown spot disease. Annals of Biology, Vol. 20, No. 2, 189-193.

Saifuila, M. 1994. Field screening of rice genotypes to brown spot and leaf scald disease, Agricultural science digest: 14 (1) 68-70.

Séré, Y. Onasanya, A. Akator, K. 2010. The biotic constraints of rice growing: Identification of rice diseases in Africa Y. y. sere @ cgiar.org.sere.y@hotmail.com Cotonou,75p.

SNRD. 2011. National Strategy for the Development of Rice Cultivation in Benin (MAEP). Final report; $26 p$ 